\title{
ANAK BEKERJA DI INDONESIA: BUKTI EMPIRIS TERHADAP WEALTH PARADOX
}

\author{
Disty Putri Ratna Indrasari \\ Program Pascasarjana Ilmu Ekonomi Universitas Indonesia \\ E-mail: distyp@gmail.com
}

\begin{abstract}
ABSTRAK. Banyak penelitian mengungkapkan bahwa keluarga yang semakin miskin akan menyebabkan kejadian anak bekerja lebih banyak (luxury axiom). Akhir-akhir ini, peneliti sudah mulai melihat adanya kondisi dimana keluarga yang mempunyai banyak tanah (keluarga yang lebih kaya), justru membuat fenomena anak bekerjanya lebih banyak (wealth paradox). Kondisi wealth paradox dibayangkan menjadi paradox dari kondisi luxury axiom. Namun demikian, kondisi wealth paradox sebenarnya dapat diintegrasikan ke dalam kondisi luxury axiom. Banyak penelitian tentang anak bekerja di Indonesia yang spesifikasi empirisnya belum dapat menangkap adanya kemungkinan perilaku wealth paradox dan luxury axiom, sehingga penelitian ini mencoba memberikan kontribusi perilaku anak bekerja di Indonesia dengan menggunakan spesifikasi empiris yang dapat menangkap perilaku wealth paradox dan luxury axiom. Penelitian ini bertujuan bertujuan untuk menguji hipotesis wealth paradox dan luxury axiom terhadap anak bekerja di Indonesia dengan menggunakan data IFLS 5. Model yang digunakan di sini adalah tobit dengan instrumental variable. Penelitian ini berhasil membuktikan secara empiris bahwa perilaku wealth paradox dan luxury axiom juga terjadi dalam konteks anak bekerja pada keluarga pertanian di Indonesia.
\end{abstract}

Kata kunci: anak bekerja; ivtobit; luxury axiom; wealth paradox; tanah.

\section{CHILD WORKING IN INDONESIA: EMPIRICAL EVIDENCE OF WEALTH PARADOX}

\begin{abstract}
Some studies on child working have shown that there is positive relationship between household poverty and child working (luxury axiom). Recently, researchers have started to see the conditions that greater land wealth leads to higher child working (wealth paradox). Seemingly, wealth paradox becomes a paradox of luxury axiom. However, the condition of the wealth paradox can be integrated into luxury axiom. Empirical spesifications some studies on children working in Indonesia have not been able to capture the possible behavior of wealth paradox and luxury axiom, so contribution of this study is using empirical specification that can capture the wealth paradox and luxury axiom of child working in Indonesia. The study aims to test wealth paradox and luxury axiom for child working in Indonesia. This study using datas number of working hours of children, land, per capita consumption expenditure, the characteristics of children, families and the environment from IFLS 5 , and tobit with instrumental variables model. The results support for hypothesis of wealth paradox and luxury axiom for child working in Indonesia.
\end{abstract}

Keywords: child working; ivtobit; land; luxury Axiom; wealth paradox.

\section{PENDAHULUAN}

Hipotesis wealth paradox sepertinya tidak sesuai dengan luxury axiom. Luxury axiom mengungkapkan bahwa keluarga yang semakin miskin akan menyebabkan kejadian anak bekerja lebih banyak, sedangkan hipotesis wealth paradox mengungkapkan bahwa keluarga yang mempunyai banyak tanah (semakin kaya) justru akan menyebabkan kejadian anak bekerja lebih banyak. Pada awalnya, Basu \& Van (1998) mengungkapkan adanya perilaku luxury axiom. Sejalan dengan Basu \& Van (1998), banyak penelitian tentang anak bekerja yang sesuai dengan perilaku luxury axiom (Nielsen, 1998; Blunch \& Verner, 2000; Ray, 2000; Delap, 2001; Amin, Quayes, \& Rives, 2004; Edmonds, 2005; dan Chiawaula, 2010). Luxury axiom melihat waktu luang anak sebagai barang mewah (Basu, Das \& Dutta, 2010; dan Fan, 2011). Sehingga, keluarga yang pendapatan selain dari upah pekerja anak lebih rendah (lebih miskin) akan mengkonsumsi waktu luang anak lebih sedikit, atau dengan kata lain keluarga miskin akan mengkonsumsi waktu anak bekerja lebih banyak. Namun demikian, akhir-akhir ini, peneliti sudah mulai melihat adanya kondisi dimana keluarga yang mempunyai banyak tanah (keluarga yang lebih kaya), justru membuat fenomena anak bekerjanya lebih banyak (wealth paradox). Fenomena itu menjadi perhatian para peneliti saat ini karena kondisi tersebut dibayangkan menjadi paradox dari kondisi sebelumnya (luxury axiom). Bhalotra \& Heady (2003) yang pertama kali mengungkapkan adanya wealth paradox. Wealth paradox biasanya terjadi di negara-negara berkembang, khususnya di daerah-daerah pertanian, dan daerah pertanian biasanya berada di area perdesaan (Bhalotra \& Heady, 2003; Basu, Das \& Dutta, 2010; dan Lima, Mesquita \& Wanamaker, 2014).

Konsep wealth paradox sebenarnya dapat diintegrasikan dalam konsep luxury axiom. Setelah Bhalotra \& Heady (2003) berhasil menangkap adanya perilaku wealth 
paradox di keluarga pertanian, kemudian Basu, Das \& Dutta (2010) mencoba mengintegrasikan wealth paradox ke dalam konsep luxury axiom. Dalam penelitiannya, Basu, Das \& Dutta (2010) menjelaskan bahwa wealth paradox itu ternyata merupakan konsekuensi dari pasar tenaga kerja tidak sempurna. Pasar tenaga kerja tidak sempurna biasanya terjadi di negara berkembang. Penelitian yang dilakukan oleh Basu, Das \& Dutta (2010) awalnya berhasil menangkap perilaku wealth paradox, artinya keluarga yang mempunyai banyak tanah akan menyebabkan anak bekerja lebih banyak pada awalnya. Akan tetapi, wealth paradox dapat terjadi sampai di suatu titik tertentu. Kemudian, jika keluarga yang memiliki atau mengoperasikan tanah terus menambah jumlah tanahnya, keluarga tersebut akan semakin sejahtera (semakin kaya), dan justru tidak menginginkan anaknya untuk bekerja, atau dengan kata lain, penambahan tanah terus menerus justru akan mengurangi anak bekerja. Artinya perilaku luxury axiom terjadi kembali dalam kasus anak bekerja. Sehingga Basu, Das \& Dutta (2010) menginformasikan bahwa, pada awalnya, peningkatan luas tanah yang dimiliki keluarga akan meningkatkan anak bekerja, lalu jika terjadi peningkatan luas tanah keluarga terus menerus justru akan menurunkan anak bekerja. Kondisi demikian disebut sebagai inverted-U. Jadi apa yang disampaikan tentang perilaku luxury axiom pada anak bekerja oleh Basu \& Van (1998) masih tetap berlaku, meskipun adanya pendapat baru yang mengatakan bahwa ada wealth paradox dalam konteks area perdesaan.

Sejalan dengan hal tersebut di atas, perlu spesifikasi empiris yang dapat digunakan untuk menangkap kemungkinan perilaku yang sesuai dengan luxury axiom maupun wealth paradox. Bhalotra \& Heady (2003); Basu, Das \& Dutta (2010); dan Lima, Mesquita \& Wanakamer (2014) secara garis besar menggunakan spesifikasi empiris yang sama, yaitu: 1) menggunakan variabel yang mewakili kesejahteraan keluarga (pendapatan keluarga atau pengeluaran konsumsi per kapita) untuk menangkap perilaku luxury axiom, 2) menggunakan variabel tanah pertanian yang dimiliki atau diolah keluarga untuk menangkap perilaku wealth paradox, 3) menggunakan variabel-variabel yang mewakili karakteristik anak, keluarga, dan lingkungan, 4) menggunakan variabel jumlah jam kerja anak untuk menggambarkan anak bekerja, dan 5) menggunakan instrumental variable untuk mentreatment variabel yang diduga endogen, yaitu penge-luaran konsumsi per kapita.

Dari penelitian-penelitian yang dilakukan oleh Bhalotra \& Heady (2003); Basu, Das \& Dutta (2010); dan Lima, Mesquita \& Wanakamer (2014) tersebut, juga dapat diketahui bahwa penelitian yang dapat menangkap kemungkinan perilaku wealth paradox dan luxury axiom mempunyai beberapa karakteristik. Pertama, obyek penelitian terkait hal ini umumnya adalah keluarga yang mempunyai bisnis pertanian, dan keluarga dengan bisnis pertanian biasanya berada di perdesaaan. Kedua, penelitian tentang wealth paradox ini juga mengambil populasi keluarga yang memiliki akses terhadap aset tanah produktif (untuk kegiatan pertanian), baik tanah yang dimiliki sendiri atau dikelola dengan cara menyewa. Ketiga, penelitian wealth paradox juga membutuhkan data atau informasi tentang keputusan anak bekerja, dan jumlah jam kerja anak untuk mengetahui penawaran tenaga kerja anak.

Penggunaan variabel tanah dan pengeluaran konsumsi per kapita dapat memberi informasi kondisi terkait wealth paradox dan luxury axiom. Pertama, terkait wealth paradox. Jika wealth paradox terjadi, ekspektasinya adalah jumlah jam kerja anak di keluarga yang memiliki luas tanah lebih besar akan lebih banyak bila dibandingkan dengan anak yang berada di keluarga yang memiliki luas tanah lebih kecil, given dua keluarga tersebut memiliki tingkat kesejahteraan yang sama. Kedua, terkait luxury axiom. Jika luxury axiom juga terjadi, ekspektasinya adalah jumlah jam kerja anak di keluarga yang memiliki tingkat kesejahteraan lebih rendah akan lebih banyak bila dibandingkan dengan anak yang berada di keluarga yang memiliki tingkat kesejahteraan lebih tinggi, given dua keluarga tersebut memiliki luas tanah yang sama.

Jika membandingkan dengan spesifikasi empiris yang dapat menangkap perilaku wealth paradox dan luxury axiom terkait anak bekerja, spesifikasi empiris penelitian di Indonesia tentang anak bekerja belum bisa menangkap perilaku kemungkinan anak bekerja terkait wealth paradox dan luxury axiom. Penelitian-penelitan terdahulu di Indonesia yang dilakukan oleh Munawaroh (2012), Nabawiyah (2014), Iryani \& Priyarsono (2013), Rizkianto, Muflikhati \& Hernawati (2013), dan Irianti \& Riasih (2015) memang sudah terkait dengan fenomena anak bekerja di Indonesia, tetapi spesifikasi empirisnya belum bisa menangkap perilaku terkait dengan wealth paradox dan luxury axiom. Hal tersebut dapat disebabkan karena penelitian-penelitian terdahulu tidak membatasi observasi hanya pada keluarga pertanian, sementara konsep wealth paradox observasinya lebih tepat dilakukan di keluarga pertanian. Sehingga spesifikasi empiris penelitian-penelitian terdahulu di Indonesia tidak bisa menunjukkan kemungkinan adanya wealth paradox di area perdesaan. Untuk menangkap bukti empiris terkait wealth paradox, penelitian ini perlu fokus kepada keluarga pertanian, dan keluarga pertanian pada umumnya berada di perdesaan (Bhalotra \& Heady, 2003; Basu, Das \& Dutta, 2010; dan Lima, Mesquita \& Wanakamer, 2014). Setelah membandingkan spesifikasi empiris yang dibutuhkan dengan penelitian yang telah dilakukan di Indonesia, penelitian ini mencoba memberikan kontribusi perilaku anak bekerja di Indonesia dengan menggunakan spesifikasi empiris yang dapat menangkap perilaku wealth paradox dan luxury axiom. 
Penelitian ini bertujuan untuk menguji adanya perilaku wealth paradox dan luxury axiom dalam konteks anak bekerja di Indonesia dengan menggunakan data data Indonesia Family Life Survey (IFLS) gelombang 5 (IFLS tahun 2014). Untuk mengetahui perilaku wealth paradox, penelitian ini akan melihat bagaimana pengaruh tanah pertanian terhadap anak bekerja dengan tetap memperhitungkan tingkat kesejahteraan keluarga.

Penelitian tentang anak bekerja yang sesuai dengan perilaku wealth paradox ini penting dilakukan karena implikasi kebijakan untuk anak bekerja yang sesuai dengan perilaku wealth paradox berbeda dengan implikasi kebijakan untuk anak bekerja yang sesuai dengan perilaku luxury axiom. Menurut Bhalotra \& Heady (2003), jika perilaku wealth paradox terbukti secara empiris, maka kebijakan untuk mengurangi anak bekerja yang sesuai dengan perilaku luxury axiom kurang efektif bila diaplikasikan untuk mengurangi anak bekerja yang sesuai dengan perilaku wealth paradox.

Batasan usia anak bekerja dalam penelitian ini merujuk pada batasan usia anak bekerja yang menurut BPS \& ILO (2009), yaitu anak-anak usia 5-17 tahun. Anak bekerja dalam penelitian ini juga dibatasi hanya anak yang berada dalam keluarga pertanian.

Untuk menjelaskan hubungan antara aset berupa tanah dengan anak bekerja, penelitian ini menggunakan teori Basu, Das \& Duta (2010). Dalam penelitian Basu, Das \& Duta (2010), dijelaskan bahwa wealth paradox terjadi di negara berkembang. Negara berkembang mempunyai pasar tenaga kerja tidak sempurna. Definisi pasar tenaga kerja tidak sempurna (dalam konteks pertanian) di sini dapat dilihat dari sisi penawaran dan dari sisi permintaan. Pasar tenaga kerja tidak sempurna dari sisi penawaran maksudnya pekerja enggan untuk menawarkan tenaganya untuk bekerja meskipun akan mendapatkan upah karena pekerja enggan untuk bekerja pada tanah atau lahan orang lain. Hal yang menjadi motivasi seseorang tidak mau bekerja pada tanah atau lahan orang lain adalah tingginya biaya untuk mencari pekerjaan, di mana biaya mencari pekerjaan tersebut berbeda-beda tiap individu, tergantung pada tempat tinggal dan jaringan sosial di mana individu tersebut berada (Goto \& Mano, 2012). Selain itu, Key, Sadoulet \& de Janvry (2000) juga menyimpulkan bahwa biaya transaksi (biaya transportasi) dapat mempengaruhi seseorang untuk berpartisipasi ke pasar tenaga kerja.

Sedangkan, jika dilihat dari sisi permintaan, maksud pasar tenaga kerja tidak sempurna adalah keluarga enggan untuk mempekerjakan tenaga kerja dari luar anggota keluarga. Hal tersebut dikarenakan adanya principal agent problem. Principal agent problem dapat terjadi karena keluarga menghadapi masalah moral hazard jika mempekerjakan tenaga kerja dari luar lingkungan keluarga. Menurut Heltberg (1998), permasalahan moral hazard terjadi ketika tenaga kerja dari luar anggota keluarga tidak terlalu peduli dan tidak berusaha optimal untuk menghasilkan output dari lahan keluarga. Jika terjadi kondisi moral hazard, artinya keluarga harus mengeluarkan tambahan waktu dan usaha untuk mensupervisi dan mengawasi tenaga kerja yang berasal dari luar anggota keluarga sehingga total biaya produksi bertambah. Selain itu, ada konsekuensi lagi jika menggunakan tenaga kerja dari luar anggota keluarga, yaitu tenaga kerja dari luar lingkungan keluarga tidak mau berbagi resiko, seperti kemampuan manajerial, dan hewan yang dibutuhkan di pertanian. Sehingga, definisi pasar tenaga kerja tidak sempurna adalah adanya keterbatasan dari sisi penawaran dan permintaan tenaga kerja yang dapat menyebabkan tidak terjadinya pasar tenaga kerja sehingga dapat memberi stimulasi kepada keluarga pemilik lahan pertanian untuk mempekerjakan anak.

Dalam penelitian Basu, Das \& Duta (2010), keluarga diasumsikan mempunyai aset tanah sebesar unit. Pada pasar tenaga kerja sempurna, jika naik, maka jumlah anak bekerja akan turun karena keluarga lebih senang mempekerjakan orang yang lebih kompeten menggarap lahan pertanian keluarga daripada mempekerjakan anak sendiri. Sebaliknya, pada kondisi pasar tenaga kerja tidak sempurna, keluarga miskin ingin mengirimkan anak mereka untuk bekerja (supaya bisa keluar dari kondisi miskin), tetapi keluarga tersebut tidak dapat mengirimkan anak mereka untuk bekerja karena tidak ada pasar tenaga kerja yang dekat dengan tempat tinggal mereka, dan orang tua tidak tega untuk mengirimkan anak mereka ke perusahaan atau pabrik yang jauh. Kemudian, jika keluarga miskin tersebut dapat memperoleh tanah, maka anak mereka akan dikirim untuk bekerja karena apa yang mereka harapkan pada awalnya dapat tercapai. Basu, Das \& Duta (2010) juga menjelaskan bahwa jika keluarga tersebut dapat terus menambah aset tanahnya sampai pada level tertentu, maka keluarga tersebut sudah tidak akan menginginkan anaknya bekerja. Dengan kata lain, peningkatan aset tanah keluarga akan meningkatkan pekerja anak pada awalnya, dan akan berkurang kemudian jika aset tanah keluarga terus bertambah, atau disebut inverted- $U$.

Diasumsikan masing-masing keluarga mempunyai fungsi utiliti dalam bentuk umum sebagai berikut:

$u=u(x$, (1) di mana:

$X_{\text {adalah total konsumsi rumah tangga }}$

e adalah jumlah anak yang bekerja

Asumsi berikutnya adalah masing-masing rumah tangga mempunyai satu orang dewasa yang bekerja (tidak peduli berapa upahnya).

Persamaan (1) secara spesifik dapat ditulis menjadi:

$u=\Phi(x)-c . e$

di mana 
di mana:

$\Phi$ adalah fungsi dari $x$.

$c$ adalah marginal return to child leisure or non work atau marginal return to child schooling. Maksud dari marginal return to child schooling adalah opportunity cost dari penggunaan waktu anak untuk bekerja dan opportunity cost tersebut menjadi pengurang utiliti keluarga. Jika anak bekerja, anak akan menghadapi opportunity cost, yaitu kehilangan marginal return to child schooling.

$\Phi^{\prime}(x) \geq 0$ dan $\Phi^{\prime \prime}(x) \leq 0$ menggambarkan diminishing marginal utility, artinya karena semakin banyak $x$ dikonsumsi, maka mengkonsumsi sejumlah tambahan $x$ akan menghasilkan penambahan utiliti yang semakin kecil (Pindyck \& Rubinfeld, 2009). Kedua pertidaksamaan ini $\left(\Phi^{\prime}(\mathrm{x}) \geq 0\right.$ dan $\left.\Phi^{\prime \prime}(\mathrm{x}) \leq 0\right)$ mempunyai nilai $x$ sampai, $x>0$ dan $C$ adalah bilangan riil positif.

Dalam pasar tenaga kerja tidak sempurna, keluarga akan mengkonsumsi apa yang diproduksi sendiri dari lahan mereka, $x=q$, sehingga fungsi utiliti keluarga menjadi $u=u(q, e)$ atau $u=\Phi(q)$-c.e. Asumsi $x=q$ menggambarkan bahwa keluarga bersifat autarki, yaitu keluarga tidak membeli barang di pasar dan tidak pula menjual surplus produksi di pasar. Sadoulet, de Janvry \& Benjamin (1996) menyampaikan dalam penelitiannya, bahwa dalam pasar tenaga kerja tidak sempurna, hal-hal yang menjadi penentu pilihan konsumsi perlu dimasukkan dalam keputusan produksi. Dalam penelitian yang dilakukan oleh Stanhill (1978) terhadap keluarga pertanian di Israel yang bersifat autarki dapat dilihat bahwa keluarga pertanian yang bersifat autarki memiliki konsekuensi, yaitu hasil produksi pertaniannya rendah, meskipun hasil produksi tersebut juga tergantung pada cuaca, kondisi tanah, kondisi tanah, dan input lainnya.

Masing-masing keluarga mempunyai fungsi produksi: $q=f(k, e+1)$

di mana:

$q$ adalah output yang diproduksi keluarga.

$k$ adalah aset keluarga berupa tanah.

$e+1$ adalah jumlah tenaga kerja yang digunakan, di mana berasal dari anak-anak, dan 1 berasal dari orang dewasa.

Asumsi yang digunakan adalah $f_{k}, f_{e}>0 ; f_{k k} f_{e e} \leq 0$; dan $f_{e k}>0$, di mana:

$f_{e k}>0$ menunjukkan kompatibiliti atau kecocokan antara anak bekerja dengan tanah atau dapat dikatakan marginal productivity of land akan meningkat jika jumlah anak bekerja ditambah, atau productivity of child work akan meningkat jika jumlah tanahnya ditambah.

Asumsi berikutnya adalah tanah bersifat immobile (aset tidak bergerak), dan keputusan untuk menjual tanah tidak diperhitungkan di sini.

Kemudian, optimisasi permasalahan keluarga menggunakan persamaan (2) dan (3) yaitu dengan cara mensubstitusikan persamaan (3) ke persamaan (2), dapat ditulis dalam persamaan berikut: $\max _{\theta} \Phi(f(k, e+1))-c e$

sehingga diperoleh first-order condition

$\Phi_{x}, f_{e}=c$

Diferensial total terhadap dan, diperoleh persamaan berikut

$\frac{d e}{d k}=-\frac{f_{\theta} \Phi_{x x} f_{k}+\Phi_{x} f_{e k}}{f_{\theta}^{2} \Phi_{x x}+\Phi_{x} f_{e \theta}}$

Untuk mempermudah penjelasan, persamaan (7) dibagi menjadi empat bagian:
i. $f_{e} \Phi_{x x} f_{k}$
ii. $\Phi_{x} f_{e k}$
iii. $f_{e}^{2} \Phi_{x x}$
iv. $\Phi_{\mathrm{x}} \mathrm{f}_{\mathrm{ee}}$

Denominator (penyebut) dalam persamaan (6) selalu bernilai negatif, jadi nilai $\frac{d e}{d k}$ tergantung pada besarnya nilai bagian i dan bagian ii. persamaan (6).

Jadi $\frac{d e}{d k}$ wealth paradox dalam Basu, Das \& Duta (2010) terjadi jika bernilai positif dan bagian ii mempunyai nilai yang lebih besar daripada bagian i, given $f_{e}, f_{k}$, $\Phi, \Phi_{x x}$

Nilai bagian i persamaan (6) dapat mendominasi jika $f_{e k}$ nilainya kecil, artinya hubungan tanah dengan anak tidak terlalu kompatibel. Hal tersebut dapat terjadi pada lingkungan industri yang menggunakan teknologi atau mekanisasi, atau pada lingkungan pertanian yang telah memanfaatkan teknologi tinggi. Sebaliknya, bagian ii persamaan (6) dapat mendominasi jika $f_{e k}$ nilainya besar (anak bekerja dapat menjadi substitusi tenaga kerja dewasa), artinya hubungan tanah dengan anak itu bersifat kompatibel.

\section{METODE}

Berdasarkan penjelasan dan teori tersebut di atas, penelitian ini akan mengestimasi hubungan antara luas lahan pertanian dan jumlah jam kerja anak di keluarga yang mempunyai aktivitas pertanian. Proksi untuk pendapatan keluarga dalam penelitian ini adalah pengeluaran konsumsi per kapita, tapi karena pendapatan keluarga dan keputusan anak bekerja dibuat dilakukan secara simultan oleh keluarga, maka ada kemungkinan pendapatan keluarga bersifat endogen dalam persamaan regresi. Selain itu, ada variabel kontrol lain yang diduga endogen dan telah terbukti setelah dilakukan uji DurbinWu-Hausman (Greene, 2008), yaitu status anak saat ini sedang sekolah atau tidak karena diduga keputusan anak bekerja dan sekolah dilakukan secara simultan.

Untuk mengatasi masalah endogenitas ini, penelitian ini akan menggunakan instrumental variable berupa variabel-variabel indikator perkembangan infrastruktur lingkungan sekitar, dan variabel yang mewakili karakteristik keluarga (Bhalotra \& Heady, 2003; Lima, Mesquita \& Wanamaker, 2014). Instrumental variable yang akan 
digunakan di sini antara lain: 1) dummy transportasi umum, 2) dummy pasar, 3) jarak pasar, 4) dummy listrik pln, 5) ketersediaan listrik pln per harinya, 6) dummy air, dan 7) produktivitas kepala keluarga (upah kepala keluarga).

Hasil pengujian empiris menunjukkan nilai signifikansi instrumental variable secara keseluruhan terhadap status anak sekolah saat ini dengan nilai $\mathrm{F}=27.31$, dan menunjukkan nilai signifikansi instrumental variable secara keseluruhan terhadap pengeluaran konsumsi per kapita dengan nilai $\mathrm{F}=127.89$. Artinya, instrumental variables tersebut mempunyai korelasi dengan variabel yang diduga endogen.

Sesuai dengan spesifikasi empiris yang dibutuhkan untuk menangkap adanya perilaku wealth paradox dan luxury axiom di Indonesia, penelitian ini akan menggunakan model tobit dengan IV. Dalam melakukan estimasi, ada dua tahap yang dilakukan dalam estimasi parameter (Bhalotra \& Heady, 2003; Cameron \& Trivedi, 2009). Tahap pertama, metode yang akan digunakan adalah OLS untuk mengestimasi persamaan variabel yang diduga endogen. Tahap kedua, metode analisis yang akan dipakai adalah prosedur standar tobit. Tahap kedua ini digunakan untuk mengestimasi persamaan anak bekerja.

Persamaan jumlah jam kerja anak $(H)$, di mana variabel bebasnya adalah censored dependent variable: $H_{i}^{*}=X_{i} \beta+Y_{i} \gamma+e_{i}$

untuk $i=1, \ldots, N$

di mana:

$H_{i}^{*}$ adalah jumlah jam kerja anak yang berasal dari keluarga pertanian

$X_{i}$ adalah vektor variabel eksogen

$Y_{i}$ adalah variabel endogen

$N$ adalah jumlah sampel.

$H_{i}=\left\{\begin{array}{l}H_{i}^{*} \text { jika } H_{i}^{*} \geq 0 \\ 0 \text { jika } H_{i}^{*} \geq 0\end{array}\right.$

Variabel terikat yang dipakai dalam penelitian ini adalah jumlah jam kerja anak. Definisi jumlah jam kerja anak adalah jumlah jam kerja seminggu yang lalu untuk anak usia 5-17 tahun yang berasal dari keluarga pertanian. Variabel-variabel bebas yang digunakan dalam penelitian ini dikelompokkan menjadi empat karakteristik, yaitu karakteristik sumber daya keluarga, karakteristik anak, karakteristik keluarga, karakteristik lingkungan.

Variabel bebas yang mewakili sumber daya keluarga adalah tanah pertanian keluarga (dalam hektar), tanah pertanian kuadrat (dalam hektar), dan persentase pengeluaran konsumsi per kapita. Variabel bebas yang mewakili karakteristik anak adalah umur anak (dalam tahun), dummy pendidikan anak, dummy status anak sekolah saat ini, dummy status hubungan anak dengan kepala keluarga, dan dummy jenis kelamin anak. Variabel bebas yang mewakili karakteristik keluarga adalah dummy kepala keluarga perempuan, jumlah anak yang berumur 18 tahun ke atas (dalam orang), jumlah orang dewasa dalam keluarga (dalam orang), jumlah anggota keluarga (dalam orang), lama sekolah kepala keluarga (dalam tahun), dan upah kepala keluarga (dalam rupiah). Sedangkan variabelvariabel yang mewakili karakteristik lingkungan semuanya digunakan sebagai instrumental variable, antara lain: dummy transportasi umum, dummy pasar, jarak ke pasar terdekat, dummy ketersediaan listrik PLN ketersediaan listrik pln per harinya (dalam jam), dummy pemakaian air PAM dan non PAM.

Sumber data yang akan digunakan pada penelitian ini adalah survei IFLS 5 dengan unit analisis jumlah jam kerja anak usia 5-17 tahun yang tinggal di perdesaan. Data IFLS memiliki keunggulan dan kelemahan. IFLS memiliki keunggulan, yaitu merupakan sumber data yang menyediakan informasi yang lengkap mengenai kraktristik individu, keluarga, maupun lingkungan (komunitas).

Penelitian ini mempunyai dua hipotesis. Pertama, jika parameter tanah bernilai positif, maka penelitian ini berhasil menangkap perilaku wealth paradox secara empiris untuk kasus anak bekerja di Indonesia. Kedua, jika parameter persentase pengeluaran konsumsi per kapita bernilai negatif, maka penelitian ini juga berhasil menangkap perilaku luxury axiom secara empiris untuk kasus anak bekerja di Indonesia.

\section{HASIL DAN PEMBAHASAN}

Analisis yang dilakukan pada penelitian ini dikelompokkan dalam dua bagian, yaitu analisis deskriptif dan analisis hasil estimasi model empiris.

Tabel 1. Statistik Deskriptif Karakteristik Sumber Daya Keluarga, Karakteristik Anak, Karakteristik Keluarga, Karakteristik Lingkungan

\begin{tabular}{lcr}
\hline \multicolumn{1}{c}{ Variabel } & \multicolumn{1}{c}{ Mean } & Std. Dev. \\
\hline (jam) & 41.2646 & 24.2043 \\
Sumber Daya Keluarga & & \\
(hektar) & 0.5191 & 1.3997 \\
(hektar) & 2.2284 & 25.6627 \\
& 15.8435 & 0.5710 \\
Karakteristik Anak & & \\
(tahun) & 10.8159 & 3.6535 \\
Karakteristik Keluarga & & \\
(orang) & 0.7511 & 0.7620 \\
(orang) & 2.1350 & 0.5016 \\
(orang) & 4.5793 & 1.7251 \\
(tahun) & 5.3881 & 4.9545 \\
(rupiah) & 932012.6 & 2269171 \\
Karakteristik Lingkungan & & \\
(km) & 2.1504 & 3.9075 \\
Observasi & 5919 & \\
\hline
\end{tabular}


Tabel 1 merupakan statistik deskriptif dari observasi terhadap anak bekerja usia 5-17 tahun pada keluarga pertanian.

Tabel 2. Hasil Estimasi Persamaan Anak Bekerja Pada Keluarga Pertanian-Koefisien

\begin{tabular}{|c|c|c|}
\hline \multicolumn{3}{|l|}{ Variabel terikat: } \\
\hline Variabel & \multicolumn{2}{|c|}{$\begin{array}{c}\text { Koef } \\
\text { (Std. Err) }\end{array}$} \\
\hline \multicolumn{3}{|l|}{ Sumber Daya Keluarga } \\
\hline (hektar) & $\begin{array}{r}7.2426 \\
(0.9916)\end{array}$ & $* * *$ \\
\hline \multirow[t]{2}{*}{ (hektar) } & $\begin{array}{r}-0.2100 \\
(0.0490)\end{array}$ & *** \\
\hline & $\begin{array}{r}-21.3851 \\
(2.5292)\end{array}$ & *** \\
\hline \multicolumn{3}{|l|}{$\underline{\text { Karakteristik Anak }}$} \\
\hline (tahun) & $\begin{array}{r}-0.1608 \\
(0.1153)\end{array}$ & \\
\hline $\begin{array}{l}(1=\text { pendidikan anak paling tinggi } \\
\text { adalah SMP ke bawah) }\end{array}$ & $\begin{array}{r}5.3568 \\
(1.4730)\end{array}$ & *** \\
\hline (1=anak sedang bersekolah) & $\begin{array}{r}-96.8182 \\
(9.2743)\end{array}$ & $* * *$ \\
\hline ( $1=$ anak kandung kepala keluarga) & $\begin{array}{r}3.2421 \\
(2.2184)\end{array}$ & \\
\hline$(1=$ anak laki-laki) & $\begin{array}{r}-0.6984 \\
(0.8363)\end{array}$ & \\
\hline \multicolumn{3}{|l|}{$\underline{\text { Karakteristik Keluarga }}$} \\
\hline $\begin{array}{l}\text { (1=kepala keluarga adalah } \\
\text { perempuan })\end{array}$ & $\begin{array}{r}5.0128 \\
(1.3343)\end{array}$ & $* * *$ \\
\hline (orang) & $\begin{array}{r}-0.2425 \\
(1.0454)\end{array}$ & \\
\hline (orang) & $\begin{array}{r}-3.6800 \\
(1.0864)\end{array}$ & *** \\
\hline (orang) & & $\begin{array}{r}-0.9494 \\
(0.5764) \\
*\end{array}$ \\
\hline (tahun) & $\begin{array}{r}1.6221 \\
(0.1458)\end{array}$ & $* * *$ \\
\hline$\underline{\text { Konstanta }}$ & $\begin{array}{r}380.9616 \\
(40.2924)\end{array}$ & $* * *$ \\
\hline Observasi & 5919 & \\
\hline
\end{tabular}

Sumber: IFLS 5, diolah.

$* * * \mathrm{p}<0.01, * * \mathrm{p}<0.05,{ }^{*} \mathrm{p}<0.1$

instumental variables: dummy public transport, dummy market, distance to market, dummy electricity, time electricity, dummy water, headwage

Tabel 2 merupakan hasil estimasi empiris.

Dari tabel 1 diketahui bahwa rata-rata jam kerja anak per minggu adalah 41 jam, atau 5-6 jam per hari. Luas lahan rata-rata yang dimiliki keluarga sebesar 0.5 hektar. Rata-rata pengeluaran konsumsi per kapita keluarga sebesar 15\%. Pada karakteristik anak untuk seluruh observasi, dapat diketahui dari tabel 1 bahwa ratarata usia anak bekerja adalah 11 tahun. Pada karakteristik keluarga untuk seluruh observasi, dapat diketahui bahwa rata-rata kepala keluarga bersekolah selama 5 tahun atau hanya bersekolah sampai kelas 5 sekolah dasar, keluarga memiliki 1 anak usia 18 tahun ke atas, 2 orang dewasa, dan jumlah anggota keluarga sebanyak 4 orang. Selain itu, kepala keluarga mempunyai upah rata-rata per bulan $\mathrm{Rp}$ 932.000,-.

Estimasi dari tobit dengan instrumental variable untuk anak bekerja usia 5-17 tahun di keluarga pertanian dapat dilihat pada tabel 4.2. Dari tabel 4.2 dapat diketahui bahwa koefisien tanah mempunyai tanda positif, artinya semakin besar luas lahan pertanian yang dimiliki atau diolah oleh keluarga, maka semakin banyak jumlah jam kerja anak. Koefisien tanah kuadrat mempunyai tanda negatif, artinya jika keluarga terus menambah luas tanah pertanian, maka jumlah jam kerja anak justru semakin menurun. Hal ini disebabkan keluarga tersebut dapat dikatakan lebih sejahtera, sehingga tidak menginginkan anaknya bekerja lagi (Basu, Das \& Dutta, 2010). Selain itu, koefisien variabel persentase pengeluaran konsumsi per kapita bernilai negatif, artinya keluarga yang lebih miskin akan mempunyai jumlah jam kerja anak lebih banyak daripada keluarga yang lebih kaya.

Tabel 2 juga dapat menunjukkan hasil estimasi terkait karakteristik anak. Koefisien dummy pendidikan tertinggi anak menunjukkan bahwa jumlah jam kerja anak pada kelompok anak yang pendidikan paling tingginya SMP ke bawah lebih banyak daripada kelompok anak yang pendidikan paling tingginya SMA ke atas. Hal tersebut dapat mencerminkan masih tingginya biaya pendidikan tingkat dasar dan menegah bagi keluarga di perdesaan sehingga memilih anaknya untuk bekerja daripada sekolah. Koefisien dummy status anak sekolah saat ini menunjukkan bahwa jumlah jam kerja anak pada kelompok anak yang sedang sekolah lebih sedikit daripada kelompok anak yang sedang tidak sekolah.

Kemudian, tabel 2 juga juga dapat menunjukkan hasil estimasi terkait karakteristik keluarga. Koefisien dummy jenis kelamin kepala keluarga menunjukkan bahwa jumlah jam kerja anak pada kelompok yang kepala keluarganya perempuan lebih banyak daripada kelompok yang kepala keluarganya laki-laki. Atau dengan kata lain, jika ibu menjadi kepala keluarga, maka akan meningkatkan jumlah jam kerja anak. Hal tersebut dapat disebabkan stabilitas ekonomi keluarga kurang baik jika ibu menjadi kepala keluarga, sehingga dapat menyebabkan anaknya ikut bekerja. Koefisien variabel jumlah orang dewasa bertanda positif, artinya semakin banyak keluarga yang mempunyai orang dewasa, maka jumlah jam kerja anak semakin berkurang. Hal ini disebabkan karena orang dewasa dapat menjadi substitusi anak bekerja. Koefisien jumlah anggota keluarga bertanda negatif, artinya semakin banyak jumlah anggota keluarga, akan mengurangi jumlah jam kerja anak karena anggota keluarga yang lain dapat menjadi substitusi untuk anak bekerja, sehingga pembagian jam kerja anak semakin sedikit. Koefisien variabel lama sekolah kepala keluarga bertanda positif, 
artinya semakin tinggi tingkat pendidikan kepala keluarga, maka jumlah jam kerja anak semakin bertambah. Hal tersebut dapat disebabkan karena semakin tingginya tingkat pendidikan orang tua, anak dapat memperoleh informasi pekerjaan lebih baik dari orang tua sehingga dapat meningkatkan jumlah jam kerja anak (Bhalotra \& Heady, 2003).

\section{SIMPULAN}

Penelitian ini menyimpulkan bahwa ternyata ada hubungan antara tanah dengan anak bekerja di Indonesia, khususnya di keluarga pertanian. Hipotesis dari penelitian ini pun dapat dibuktikan secara empiris. Hasil dari penelitian ini mengkonfirmasi bahwa perilaku wealth paradox juga dapat berlaku untuk anak bekerja di Indonesia, khususnya pada keluarga pertanian yang tinggal di area perdesaan. Begitu pula dengan luxury axiom juga berlaku untuk anak bekerja di Indonesia, khususnya pada keluarga pertanian yang tinggal di area perdesaan. Kondisi ini dapat menggambarkan bahwa jumlah jam kerja anak di keluarga yang punya tanah lebih luas akan lebih banyak daripada anak di keluarga yang punya tanah lebih sempit, given pengeluaran konsumsi per kapitanya sama. Atau, jumlah jam kerja anak di keluarga lebih miskin akan lebih banyak daripada anak di keluarga yang lebih kaya, given punya luas tanah yang sama. Selain itu, penelitian ini juga menyimpulkan bahwa meskipun jumlah jam kerja anak meningkat seiring bertambahnya luas lahan pertanian keluarga, tetapi penambahan luas tanah yang terus menerus justru akan menurunkan jumlah jam kerja anak. Artinya perilaku inverted-U juga terbukti secara empiris untuk anak bekerja di Indonesia. Pada akhirnya, penelitian ini juga menyimpulkan bahwa aset keluarga berupa tanah pertanian merupakan salah satu indikator yang dapat menyebabkan anak bekerja untuk kondisi pasar tenaga kerja tidak sempurna

\section{UCAPAN TERIMA KASIH}

1. Dr. Arie Damayanti, Program Pascasarjana Ilmu Ekonomi Universitas Indonesia

2. Pusat Pembinaan, Pendidikan dan Pelatihan Perencana (Pusbindiklatren) Bappenas

\section{DAFTAR PUSTAKA}

Amin, S., Quayes, M. S. \& Rives, J.M. (2004). Poverty and Other Determinants of Child Labor in Bangladesh. Southern Economic Journal, 70, (4), 876-892.

Basu, K. \& Van, P.H. (1998). The Economics of Child Labor. The American Economic Review, 88, (3), 412-427.
Basu, K., Das, S. \& Dutta, B. (2010). Child Labor and Household Wealth: Theory and Empirical Evidence of an Inverted-U. Journal of evelopment Economics, 91, (1), 8-14.

Bhalotra, S. \& Heady, C. (2003). Child Farm Labor: The Wealth Paradox. World Bank Economic Review, 17, (2), 197-227.

Blunch, N. H. \& Verner, D. (2000). Revisiting the Link Between Poverty and Child Labor: The Ghanaian Experience. Policy Research Working Paper, 2-21.

BPS, \& ILO. (2009). Pekerja Anak Indonesia 2009. Jakarta: Badan Pusat Statistik.

Cameron,A. C.\& Trivedi, P.K. (2009). Microeconometrics Using Stat a. Texas: Stata Press.

Chiawaula, L.S. (2010). Household Poverty and Child Labor Decisions in Malawi. Research in Labor Economics, 31, 33-51.

Delap, E. (2001). Economic and Cultural Forces in The Child Labour Debate: Evidence from Urban Bangladesh. The Journal of Development Studies, 37, (4), 1-22.

Edmonds, E.V. (2005). Does Child Labor Decline with Improving Economic Status?. The Journal of Human Resources, 40, (1), 77-99.

Fan, C.S. (2011). The Luxury Axiom, The Wealth Paradox, and Child Labor. Journal of Economic Development. 36, (3), 25-45.

Goto, H. \& Mano, Y. (2012). Labor Market Competitiveness and The Size of The Informal Sector. Journal of Population Economics, 25, (2), 495-509.

Greene, W.H. (2008). Econometric Analysis. New Jersey: Pearson Prentice Hall.

Heltberg, R. (1998). Rural Market Imperfections and The Farm Size-Productivity Relationship: Evidence from Pakistan. World Development, 26, (10), 1807-1826.

Iryani, B.S. \& Priyarsono, D.S. (2013). Eksploitasi terhadap Anak yang Bekerja di Indonesia. Jurnal Ekonomi dan Pembangunan Indonesia. 13, (2), 177-195

Key, N., Sadoulet, E. \& de Janvry, A. (2000). Transactions Cost and Agricultural Household Supply Response. American Journal Agricultural Economics, 82, (2), 245-259.

Lima, L.R., Mesquita, S. \& Wanamaker, M. (2014). Child Labor and the Wealth Paradox: The Role of Altruistic Parents. Economics Letters, 130, (C), 80-82. 
Munawaroh, T. (2012). Pengaruh Kemiskinan Rumah Tangga Terhadap Penawaran Tenaga Kerja Anak di Indonesia. Tesis Program Pascasarjana Ilmu Ekonomi Universitas Indonesia.

Nabawiyah, M. (2014). Pengaruh Kredit Terhadap Pekerja Anak di Provinsi Kalimantan Selatan. Tesis Program Pascasarjana Ilmu Ekonomi Universitas Indonesia .

Nielsen, H.S. (1998). Child Labor and School Attendance: Two Joint Decisions. Centre for Labour Market and Social Research, 1-32.

Pindyck, R.S. \& Rubinfeld, D.L. (2009). Microeconomics. New Jersey: Prentice Hall.

Irianti, D. \& Riasih, T. (2015). Dukungan Pemerintah Daerah Terhadap Penanganan Anak Jalanan di
Kota Pontianak, Propinsi Kalimantan Barat. Sosiohumaniora, 17, (1), 13-20.

Ray, R. (2000). Child Labor, Child Schooling, and Their Interaction with Adult Labor: Empirical Evidence for Peru and Pakistan. The World Bank Economic Reiew, 14, (2), 347-367.

Rizkianto, R., Muflikhati, I. \& Hernawati, N. (2013). Nilai Ekonomi Anak, Motivasi, dan Self-Esteem Pekerja Anak. Jurnal Ilmu Keluarga dan Konsumen. 6, (3), 172-179

Sadoulet, E., de Janvry, A. \& Benjamin, C. (1996). Houshold Behavior with Imperfect Labor Markets. Journal of Industrial Relations. 37, (1), 85-108

Stanhill, G. (1978). The Fellah's Farm: an Autarkic AgroEcosystem. Agro-Ecosystems. 4, (4), 433-448. 